\title{
Velocity of Micro Finance among Users Groups in Delta State, Nigeria
}

\author{
F.O. Achoja \\ Dept of Agricultural Economics \& Extension \\ Delta State University \\ Asaba Campus
}

Received: August 11, 2010

Accepted: July 5, 2011

doi:10.5539/ijef.v3n4p48

\begin{abstract}
The velocity of micro finance among User Groups in Delta State was investigated Snow ball sampling technique was adopted in selecting 15 micro finance Users Groups for the study A five - year panel data $(2000-2004)$ was collected with the aid of questionnaire Data collected was analysed with the aid of descriptive statistics, efficiency model, regression and correlation models. The result of the study shows that a mean of N18,655.33 was discoursed to each member as loan, while a mean of N14,965.50 was repaid by each member of the group. Since the mean amount repaid is not significantly different from mean amount borrowed, $\mathrm{t}$-cal $1.17<\mathrm{t}$-crit, $1.86(\mathrm{P}>0.05)$. The null hypothesis which states that there is no significant difference between the amount borrowed and amount repaid was uphold. This implies that the micro finance user groups were efficient in loan repayment/recovery ability. The micro finance users groups recorded loan administration efficiency of $80.20 \%$. A historical coefficient of variation of $14.77 \%$ and $13.8 \%$ indicate a steady growth rate in amount of loan disbursed and recovered respectively. It was therefore recommended that micro finance user groups should form linkage with financial institutions for the purpose of credit mobilization scheme.
\end{abstract}

Keyword: Efficiency, Micro finance, Users groups, Credit, Administration

\section{Introduction}

As farming the Nigeria is gradually transformed from a subsistence to commercial orientation, capital and finance challenges tend to become increasingly important. Cash is needed din the form of micro credit to finance farm expansion and to off set production cost such as tractor hiring purchase of modern technologies such as fertilizers, seed/seedlings, agrochemicals and labour hiring. Cramer et al, (2001), attributed the boom and bust in agriculture in the USA to the efficiency of credit institutions in farm credit administration. This can also be achieved in Nigeria. Credit needs of the farmers must fall within the borrowing limits imposed by lenders or by the farmer own attitude to debt, interest charge and income flows.

Several studies have revealed that credit from the formal sector of financial market in Nigeria, accounted for only a small proportion of farmers loan. Loan defaults and losses have created some crises and inefficiency in the formal financial sector. Ojo (1998) reported that farm credit granted were either improperly utilized or allocated to non-farmers and were never repaid. However members of credit user groups are serving as agent for development, by pulling their resources together and gaining corporate access into the financial markets (Odusola, 1997).

It is important to identify Farm Credit Users groups and investigate how efficiently they administer credit to their members. Efficiency of credit institutions in terms of credit administration has increasingly become an interesting topical issue in economic debates. The efficiency of some agricultural lending institutions was reported to be low. Some operated with losses and collapsed when government could not sustain them financially. Cheap credit policies which often implies high transaction cost and negative real interest rates could have been responsible for the poor performance of credit institutions (Adams, 1998).

World Bank (2008) maintained that the main determinants of inefficiency of lending institutions could be traced to high default rates and transaction costs for processing, loan monitoring and cost of enforcing small loans. These factors tend to increase the break-even rate for loans.

Efficiency of farm credit Users-Groups may determine how well they could maintain competition with other lending institutions in loan administration. Investigating the efficiency of micro finance user group will demonstrate how well they are able to fill the gap between their members and formal lending institutions in Delta State, Nigeria. Empirical information is lacking in this respect before now. This study was therefore designed to fill this information gap.

\section{Objectives of the Study}

The broad objective of this study is to investigate the efficiency of micro finance Users Groups in credit administration in Delta State, Nigeria. Specifically, the study was designed to: 
(i) ascertain amount of credit disbursed by microfinance Users Groups in the study area from 2000 to 2004 .

(ii) determine the percentage repayment efficiency of members of microfinance Users Groups

(iii) estimate the operational efficiency of microfinance users groups in the study area.

(iv) estimate the relationship between loan disbursement and recovery of microfinance Users Groups in the study area.

\section{Concept of Microfinance}

The concept of microfinance refers to the provision of financial services-loans, savings or insurance transferred to low-income or resource-poor groups. In recent times, most donor interventions tend to concentrate on micro-credit as one of the microfinance services. According to Oluwalana et al (2004), micro-credit ranges between $\$ 20,000$ and $\$ 100,000$.

It is rather unfortunate that the efforts of Nigerian governments towards agricultural development through the use of formal credit institutions have not been effective. Indeed most of the credit institutions have not able to make a significant impact due to several operational deficiencies among which are gross inadequacies in management and poor loan recovery performance (Olomala, 1994; Oluwalana et al, 2005).

According to Ike and Ajieh, (2009) formal credit programmes have failed to deliver credit to target farmers and rural economic agents. They have failed in promoting a viable credit delivery system in the country. This weakness gave rise to the penetration of informal credit users into the agricultural credit market. The essence is to form linkage or intermediation between formal financial institutions and credit users groups.

\section{Theoretical Framework}

This study was predicated on three theories viz; credit market, credit groups and efficiency theories.

Abbott and Makeham (1990) defined credit as the accessibility to the right to obtain and use financial capital which must be paid back at a specified period of time. Baker (1969) distinguished between credit and loan in such a way that credit is regarded as a financial reserve or asset for a borrower and credit becomes a loan as soon as the borrower starts to spend it and incurs interest charged on it. Credit market is different from commodity market in that the right of ownership to credit is temporary be it short term or long term; while that of commodity is permanent.

Abbot and Makeham (1990) define the concept of credit as access to capital which will be paid at a latter date. Their idea about credit is that through credit a farmer could used capital when needed and at price (interest) paid to mobilize such credit and direct it into profitable ventures. Ijere (1998) reviewed that credit is a catalyst that activates other factors of production. It makes unused capital functional for increased production. Micro Credit is operationally defined as a financial instrument in the absence of adequate personal savings and which must be repaid within a period of one year.

The assumption behind credit is that without credit very little happens in farming and improved technology will not be adopted. Balogun and Otu (1999) hypothesized that farmers demand for credit was influenced mainly by availability of credit subsidies, relative farm profitability and availability of guarantors.

However, Credit market condition for financial services. Hence demand and supply of financial services respond to interest rate charged (i.e price). Short term loans attract lower interest rate then longer term loans. As the flow (supply) of money in credit market fluctuates, the rate of interest tends to rise and fall. Accordingly Besey (1996) hypothesized that credit is assumed to respond to gains from trade. The expected and actual profitability of the agricultural activity would have a great influence on the farmer's decision and ability to borrow or demand for credit, since credit must yield profit to allow repayment of capital and transaction cost.

To the supplier of financial service (Users Groups), credit must yield profit to allow repayment of capital (capital flow) to formal sources and to cover transaction cost. To the user of financial instrument, credit must yield profit to boost investment and to allow repayment.

Credit marketing involves the flow of financial instrument (idle funds) from a source (formal or informal), through intermediaries (Users Groups) to an end user (users group members). Benefiting members use the credit as catalyst to boost their farm production and related activities. At the expiration of the loan duration, the loan is channeled back to the source through repayment/recovery process. The rate of repayment of credit and subsequent demand for loan is an indicator of the financial viability of the borrower.

Financial intermediation is the process of channeling surplus money from a lender to a borrower through a medium (e.g cooperative) at a price called interest. The lenders of fund are usually called surplus saving units (SSUs). These 
can be individuals, business firms, Non-governmental organizations (NGOs), or even the government and are ready to release it temporarily. Deficit saving unit (DSUs), on the other hand, are individuals or organizations that need more money then they currently have so as to satisfy some needs; and are willing to obtain the needed fund at the ruling rate of interest. Hence SSU occupies the supply side, while the DUSs represents the demand side of micro finance market. Financial intermediaries are institutions (e.g cooperatives), which serve as links between the surplus and the deficit units.

Financial intermediaries can be divided into two broad categories (i) the banking institution (i.e financial institutions that operate as banks) and (ii) the non-bank financial institutions (Iyoha et al, 1998).

Kazeen and Nwize (1998) reviewed that mobilization involves the pooling of all available resources for an effective operation. Credit mobilization involved the pooling of credit facilities (idle funds) from a source (formal or informal), through intermediaries by way of credit delivery/administration to an end user (e.g the Farmer) for utilization Adam (1998), had earlier asserted that credit obtained must be repaid according to agreed terms. An efficient credit repayment system encourages credit recycling. This is schematically presented below:

\section{Insert Figure 1 Here}

The rate of repayment of credit and subsequent demand for loan is an indicator of the financial viability of the borrower or group of borrowers. And this enhances the sustainability of a credit system. If the borrower makes enough profits in his farming enterprises to repay the loan, this becomes a motivator to make a repeat application for loan or demand for another.

High default rate is as a result of credit leakages among small-scale farmers credit leakages is as a result of loan diversion to unintended purposes such as social demands and domestic needs such feeding, payment of children school fees, medication ad house recent. A loan that leaked from the cycle can hardly be recovered. It is hoped that micro finance groups using group dynamics can perform efficiently in credit administration. Group approach to micro finance administration is believed to posses some potentials in reducing credit leakages.

\section{Research Methodology}

\section{Study Area, Sample Techniques and Data Collection Techniques}

The study was carried out in Delta State of Nigeria. It is one of the states in the Niger-Delta region of Nigeria. This area was chosen for the study because majority of the people are small scale farmers who organized themselves into self-help financial groups. The major economic activities include farming, agro-allied industries and petty trading. Snow ball sampling technique was adopted in selecting 5 self-help groups (cooperative societies) from each of the 3 agro-economic zones. Hence a total of 15 self-help groups were selected and studied. Historical data were collected with the use of structured questionnaire information on credit transaction for 5 years (2000 to 2004). Data were collected on the amount of credit obtained; among repaid, interest charged, loan transaction costs.

\section{Data Analysis Techniques}

Collected data were analysed using a combination of descriptive and inferential statistical tools. Means volume of loan administered per user group was determine by dividing the total amount disbursed for the five year period by the number of user group surveyed. Coefficient of variation(c.v) was used to determine the velocity of micro finance among user group for the period under study. The velocity of micro finance measures the rate of flow of micro finance from the source to user group members over time. The mean volume of loan repaid was also determined through similar procedure. Loan repayment efficiency ratio was determined as follows:

Loan Repayment Efficiency Ratio (LORER) = Amount Repaid

\section{Amount borrowed}

The percentage repayment Efficiency was evaluated as follows:

$\%$ Repayment Efficiency

$$
=\frac{\text { Amount repaid }}{\text { Amount borrowed }} \times \frac{100}{1}
$$

The degree of relationship between loan repayment and loan repayment and loan disbursement was measured with the aid of simple regression model. This is explicitly stated as:

$\begin{array}{lll}\mathbf{Y}_{\boldsymbol{\beta}} & =\boldsymbol{\alpha}+\boldsymbol{\beta}_{\mathrm{REPT}}+\mathrm{Ui} \\ \text { Where } & \mathbf{Y}_{\boldsymbol{\beta}} & =\text { Amount borrowed (N) } \\ \mathbf{R E P T} & =\text { Repayment } \\ \boldsymbol{\alpha} & =\text { Intercept term }\end{array}$




\section{$\beta=$ Parameter estimate \\ $\mathbf{U}=$ Error term}

\section{Results and Discussion}

\section{Amount of Micro Finance Disbursed}

The amount of credit disbursed by micro finance User Groups in the study area within the period of the study is presented in table 1 .

\section{Insert Table 1 Here}

The result shows that the mean amount of $\$ 18,655.33$ was disbursed to members of farm credit Users groups within the period of the survey with a historical standard deviation of $\$ 2755.79$ and historical coefficient of variation of $14.77 \%$ indicating credit velocity $14.77 \%$ per year. This result implies that the rate of improvement in the volume of loan disbursed by farm credit users Groups was as high as $14.77 \%$ within 5 years $(2000-2004)$ period that was surveyed. Micro finance users Groups were indeed efficient on the basis of steady growth (14.77\%) in the volume of loan they channeled to their members. If supported by financial institutions in this respect, they could do more. This will result in improvement in output and economic well being of the groups members.

\section{Efficiency in Loan Recovery/Repayment}

The distribution of credit recovery/repayment efficiency of farm credit Users Groups within the period of the survey $(2000-2004)$ in the study areas is presented in table 2.0

Insert Table 2 Here

The result showed that about N3,370,857.2 mean amount recovered by the all credit users groups within the 5 years period under review. About N223,723.30 was the mean amount of loan recovered per user group with the period ( 2000 - 2004, while about N14,965 was the mean amount of loan repaid per member of the user groups in the study area.

The implication of the finding is that within the survey years $(2000-2004)$, farm credit user groups growth rate of $13.85 \%$ in loam repayment in the study area.

Furthermore, loan administration efficiency ratio was evaluated by suing the formula below:

\begin{tabular}{|c|c|c|}
\hline \multirow[t]{2}{*}{ Load eff: } & \multicolumn{2}{|c|}{ interest charged } \\
\hline & \multicolumn{2}{|c|}{ Loan transaction cost } \\
\hline \multirow[t]{2}{*}{ Load eff $=$} & $\$ 1,685425.60$ & $=2.25$ \\
\hline & $\$ 750,773.30$ & \\
\hline \multicolumn{2}{|c|}{ Loan Transaction Cost } & $\mathbf{N}$ \\
\hline \multicolumn{2}{|c|}{ Exco sitting allowance } & 105500 \\
\hline \multicolumn{2}{|c|}{ Committee allowance } & 22700 \\
\hline \multicolumn{2}{|l|}{ Transportation } & 31900 \\
\hline \multicolumn{2}{|l|}{ Bank charges } & 425633.30 \\
\hline \multicolumn{2}{|c|}{ Communication } & 97000 \\
\hline \multicolumn{2}{|l|}{ Stationeries } & 68040 \\
\hline \multicolumn{2}{|l|}{ Total } & $\$ 750,773.30$ \\
\hline
\end{tabular}

(Source: 2004 field survey)

This implies that for every N100 transaction cost incurred by farm credit user groups, they could earn a return of N125. Furthermore loan repayment performance was evaluated using student $t$-test to test the difference between mean amount borrowed and mean amount repaid $\mathrm{t}_{\text {-cal }}(1.71) \mathrm{t}_{\text {-crit }}(1.86)$ at $(\mathrm{P}>0.05)$

This shows that there is no significant difference between amount disbursed and amount repaid. With this the null hypothesis is upheld. This was used as loan repayment performance criterion of farm credit users groups in the study area. Members of farm credit users group have indeed performed very well in loan repayment. Where loan repayment performance is high, default rate and credit leakages are usually minimal. All these are important features 
that boost the confidence and integrity of microfinance banks. This will attract continuous patronage and support of funding institution and agencies.

\section{Relationship between Short Term Loan Disbursement and Recovery}

The relationship between the amount of short term loan disbursed and recovered by farm credit users groups in Delta State was evaluated with the use of correlation coefficient and simple regression models. The correlation coefficient $(r)=0.9$ and the simple regression equation, showed that there is positive and significant relationship between the amount of short-term loan disbursed and recovered by farm credit users groups in Delta State. The result implies that loan repayment index is an important and significant determinant of the amount of fund available for further disbursement of micro finance. Micro finance users groups in the study area are effective enough to have a high repayment rate of $80.2 \%$. Where short term loan recovery is defective, micro finance users groups could stifled due to fund shortages. Under such situations, consideration of loan applications would delay. Loan recovery Performance is a reliable measure of efficiency of micro finance groups.

\section{Conclusion/Recommendation}

The investigation of efficiency of micro finance users group in credit administration in Delta State, revealed some useful facts. Credit disbursement and recovery grew at $14 \%$ and $13 \%$ respective over the period of 5 years (2000 2004) under review. This steady growth in micro-finance mobilization has some fundamental implication. Farm size (acreage), farm income, and hence welfare of credit users must have improved considerably after obtaining loan. Huge capital required for farm investments cannot be made by the farmers personal savings but by loans. Thus loan availability could solve the problem of capita shortages that tend to impede agricultural and economic development of small scale farmers in developing countries. Since micro finance users groups have demonstrated high degree of efficiency in credit administration they should be encouraged to form linkages with formal financial institutions such as the bank of industry and other commercial banks in the area of micro finance/revolving loan schemes.

\section{References}

Abott, J.C and Makeham, J.P (1990) Agricultural Economics and Marketing in the Tropics (2 ${ }^{\text {nd }}$ edition) London: Longman. Pp. 170

Adam, D.W. (1998). The Economics of Lending to Informal Groups of Small Farmers in Low Income Countries, Dept of Agricultural Economics, Ohio State University, Ohio (Unpublished).

Adekanye, T.O. (1983). Agricultural Credit in Africa: Implication of the Nigeria Experiment" Agricultural Administration and Extension 14 (3), 203 - 211.

Ajakaiye, M.B. (1986). The role of Nigeria Agricultural and Cooperative Bank in Nigeria. In Osuntogun. A and R. Ugorji (eds) Financing Agricultural Development in Nigeria.

Arene, C.J. and Okpakpera. (2006). Economic Agricultural Production to the Micro and Macro level Perspectives, Enugu. Price Publishing Co.

Besky, S.S. (1994). Can Africa find Lasting means of Addressing Poverty - on the continent? Sunday Time, June Pp.6.

Crammer, G.L., C.W. Jensen and D.D. Southgate (Jr) (2001). Agricultural Economics and Agribusiness, New York: John Wiley and Sons, Inc.

Ehigiamusoe, G. (2000). Poverty and Microfinance in Nigeria, LAPO Development Centre, Benin: Ob-zed Publishers Pp. 9 - 12

Ijere, M.O. (1998). Agricultural Credit and Economic Development. In Readings in Agricultural Finance Ibadan: Longman Plc.

Iyoha, M.A; S.A. Oyefusi and D.E Oriakhi. (1998). An Introduction to Modern Macroeconomics; Benin: Mindex Pub. Co. Ltd

Ike P.C and Ajieh, P.C. (2009). Micro Financing and Poverty Alleviation Measures for Rural Development: The Role of Non-Governmental Organization in Nigeria In Agbamu, J.U (ed) Perspectives In Agricultural Extension and Rural Development Pp. 309.

Ojo, M.O. (1998). Some Implications of Government Economic Policies for the Financial and Development of Agriculture in Nigeria: Readings in Agricultural Finance; Ibadan: Longman Nigeria Plc.

Olomila, A.S. (1994). Loan Administration and Utilization Under the Graduate Agricultural loan schemes in Nigeria. NISER Individual Research Project Report, No. 2 Ibadan. 
Oluwalana, E.O.A., Okuneye, P.A and Sokoyo, G.O. (2004). Micro Credit for Agricultural Development. A Study of Women Groups in Ogun State Nigeria.

Otu, M.F. (2003). Informed Credit Market and Monetary Management in Nigeria, Occasional Paper, Central Bank of Nigeria Research Department, No. 29, Pp. 5 - 10.

World Bank. (2008). Annual Report

Table 1. Amount of Credit Disbursed by Farm Credit Users groups

\begin{tabular}{|l|l|l|l|}
\hline Year & Total volume of credit (\$) & Mean volume of loan disbursed by Credit Groups (\$) & Mean volume of loan obtain by members \\
\hline 2000 & 3460,6000 & 230706.6 & 15.380 .40 \\
\hline 2001 & 360003000 & 240020 & $16,001.30$ \\
\hline 2002 & $4,47.600$ & 298040 & $19,969.40$ \\
\hline 2003 & 47056300 & 313686.67 & 20912.40 \\
\hline 2004 & 4750450 & $316,696.67$ & 21.113 .10 \\
\hline
\end{tabular}

$\bar{Y}=\# 18,655.33$
$\mathrm{SY}=\mathrm{C} . \mathrm{V}=14.77 \%$

Table 2. Distribution of Farm Credit Users Groups in Load Recovery/Repayment

\begin{tabular}{|c|c|c|c|}
\hline Year & Total volume of credit ( $\mathrm{N}$ ) & Amount of loan Recovered per Groups ( & 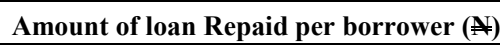 \\
\hline 2000 & $2,837,692$ & 189179.46 & $12,611.90$ \\
\hline 2001 & 2888024 & 192016.00 & $12,801.00$ \\
\hline 2002 & $3,685.890$ & 240,726 & $16,301.70$ \\
\hline 2003 & 3,670134 & 244675 & $16,311.70$ \\
\hline 2004 & $3,780,300$ & 252020 & $16,801.00$ \\
\hline Total & $16,854.256$ & $1,118,616.50$ & 74827.30 \\
\hline $\begin{array}{l}\text { e: } 200 \\
= \\
= \\
=\end{array}$ & $\begin{array}{l}\text { field survey) } \\
\text { N14,965.50 } \\
\text { N2073.1 } \\
13,85 \%\end{array}$ & & \\
\hline
\end{tabular}

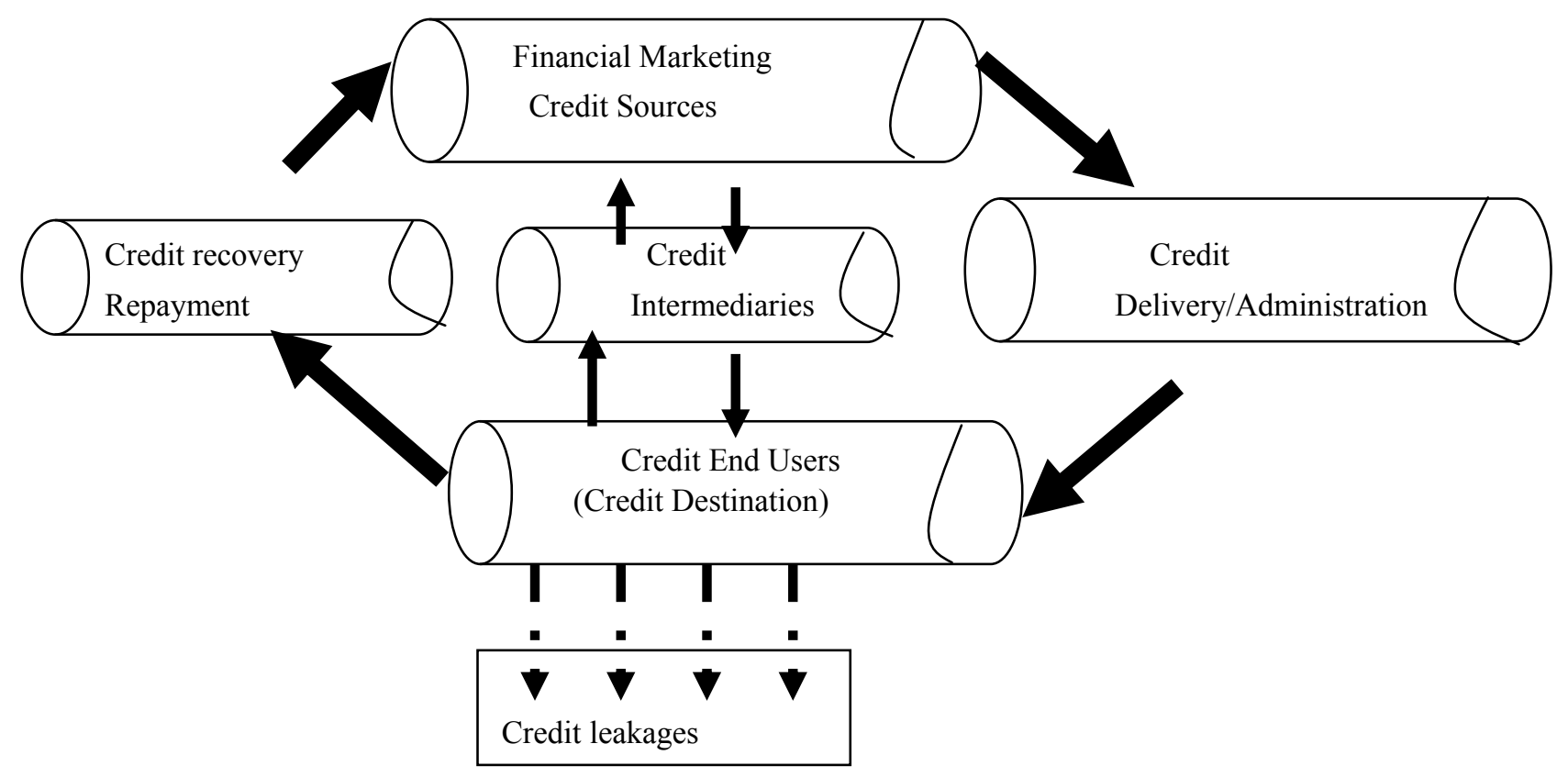

Figure 1. Micro Finance Marketing/Mobilization Cycle 